\title{
ШЛЯХИ ВДОСКОНАЛЕННЯ ДІЯЛЬНОСТІ СИСТЕМИ СПОРТИВНОГО АРБІТРАЖУ ТА ТРЕТЕЙСЬКИХ СУДІВ У СПОРТІ
}

\author{
Марина Саннікова ${ }^{1}$ \\ ${ }^{1}$ Харківська державна академія фізичної культури, м. Харків, Україна, svetlanastadnik87@ gmail.com
}

https://doi.org/10.29038/2220-7481-2019-02-21-27

\begin{abstract}
Анотації
Актуальність теми дослідження. Сучасний спорт належить до розважального шоу-бізнесу. У його основу покладено комерційні інтереси. Однак він не може існувати без тісного зв'язку з політичною, економічною й соціальною системами суспільства. Він також не може існувати й поза загальною національною правовою системою. У зв’язку з цим актуалізується значущість наукових досліджень міжнародного спортивного арбітражу 3 погляду системного підходу. Мета дослідження - вивчення та аналіз системи міжнародного спортивного арбітражу як основного інституту вирішення конфліктів, пов'язаних зі спортом, для формування в Україні сучасного Спортивного арбітражного суду. Методи дослідження - аналіз та узагальнення літературних джерел; аналіз документальних матеріалів; метод історизму; метод аналогії досліджуваних закономірностей; системний аналіз. Результати дослідження. Визначено й обгрунтовано правову основу функціонування міжнародного спортивного арбітражу, зокрема досліджено особливості, основні функції міжнародного спортивного арбітражного процесу та нормативноправові документи, що регламентують діяльність суду. Представлено шляхи подальшого реформування й удосконалення діяльності Міжнародного спортивного арбітражного суду. Висновки. 3'ясовано найбільш характерні недоліки наявної системи організації правової діяльності в спорті. Установлено основну причину невирішеності наявних труднощів в управлінні галуззю спорту вищих досягнень. Виявлено необхідність звернення до загальної теорії систем, що самоорганізуються. Запропонований підхід дасть змогу створити більш ефективну правову основу організації системи управління діяльністю арбітражних і третейських судів у спорті.
\end{abstract}

Ключові слова: спортивний арбітраж, суд, спорт, конфлікт, спортивне право.

Марина Санникова. Пути совершенствования деятельности системы спортивного арбитража и третейских судов в спорте. Актуальность темы исследования. Современный спорт принадлежит к развлекательному шоу-бизнесу. В его основе лежат коммерческие интересы. Однако он не может существовать без тесной связи с политической, экономической и социальной системами общества. Он также не может существовать и вне общей национальной правовой системы. В связи с этим актуализируется значимость научных исследований международного спортивного арбитража с точки зрения системного подхода. Цель исследования - изучение и анализ системы международного спортивного арбитража в качестве основного института разрешения конфликтов, связанных со спортом, для формирования в Украине современного Спортивного арбитражного суда. Memoды исследования - анализ и обобщение литературных источников; анализ документальных материалов; метод историзма; метод аналогии исследуемых закономерностей; системный анализ. Результаты исследования. Определяется и обосновывается правовая основа функционирования международного спортивного арбитража, в частности исследуются особенности, основные функции международного спортивного арбитражного процесса и нормативно-правовые документы, регламентирующие деятельность суда. Представлены пути дальнейшего реформирования и совершенствования деятельности Международного спортивного арбитражного суда. Выводы. Выясняются наиболее характерные недостатки существующей системы организации правовой деятельности в спорте. Установлена основная причина неразрешимости существующих проблем в управлении отраслью спорта высших достижений. Выявлена необходимость обращения к общей теории самоорганизующихся систем. Предложенный нами подход позволит создать более эффективную правовую основу организации системы управления деятельностью арбитражных и третейских судов в спорте.

Ключевые слова: спортивный арбитраж, суд, спорт, конфликт, спортивное право.

Marina Sannikova. Ways to Improve the Activities of the Sports Arbitration System and Arbitration Courts In Sports. Relevance of the Research Topic. Modern sport belongs to the entertainment show business. It is based on commercial interests. However, it cannot exist without a close connection with the political, economic and social systems of society. It also cannot exist outside the general national legal system. In this regard, the importance of scientific research of international sports arbitration is actualized from the point of view of a systems approach. The Purpose of the Research is studying and analyzing the system of international sports arbitration as the main institution for resolving conflicts related to sports, in order to form a modern sports arbitration court in Ukraine. Methods of Research - analysis and synthesis of literary sources; analysis of documentary materials; the method of historicism; method of analogy of the studied laws; system analysis. Results of the Study. The legal basis for the functioning of international sports arbitration has been determined and 
substantiated, in particular, the features, main functions of the international sports arbitration process and legal documents regulating the activities of the court have been investigated. The ways of further reforming and improving the activities of the Court of Arbitration for Sport are presented. Conclusions. The most characteristic shortcomings of the existing system of organizing legal activities in sports have been clarified. The main cause of the insolubility of the existing problems in the management of the industry of higher achievements of sport has been established. The necessity of addressing the general theory of self-organizing systems is revealed. The proposed approach will allow us to create a more effective legal basis for organizing the system for managing the activities of arbitration and arbitration courts in sports.

Key words: sports arbitration, court, sport, conflict, sports law.

Вступ. Істотні зміни соціальної значимості професійного спорту викликали необхідність формування правової основи його регулювання як у межах України, так і в усьому світі. Це визначило потребу грунтовніших досліджень особливостей сучасного розвитку спорту. Одним із важливих компонентів у цих дослідженнях $є$ формування міжнародного спортивного права та системи міжнародного спортивного арбітражу. Це пов'язано з тим, що звичайні судові інстанції не пристосовані до вирішення конфліктних ситуацій, які постійно виникають у спортивному світі.

Для розв'язання конфліктних ситуацій, пов'язаних зі спортом, нині діють спортивні арбітражні суди, такі як Міжнародний спортивний арбітражний суд (англ. - Court of Arbitration for Sport, CAS, фp. Tribunal Arbitral du Sport, TAS), спортивні арбітражні комісії (суди) у Бельгії, Німеччині, Іспанії, Італії, Люксембурзі, Франції та в інших країнах світу. Створюються арбітражі й у загальноєвропейських спортивних організаціях, наприклад у Європейському народному спортивному русі [5; 6; 7].

Аналіз останніх досліджень і публікацій показав, що діяльність спортивного арбітражу викликає науковий інтерес у вітчизняних та зарубіжних учених $[5 ; 6 ; 15 ; 16 ; 19]$. Зокрема, С. В. Ніколюкін [7] розглядає спортивний арбітраж як регулятор конфліктів у сфері спорту. Розв'язання конфліктних ситуацій, що виникають у спорті, є предметом дослідження Holt N. L., Knight C. J. \& Zukiwski P. [17]. Водночас із позиції системного підходу діяльність арбітражних судів на сучасному етапі, на жаль, не розглядалась у наукових працях, що зумовлює актуальність дослідження цієї проблематики.

Мета дослідження - вивчення та аналіз системи міжнародного спортивного арбітражу як основного інституту вирішення конфліктів, пов'язаних зі спортом, для формування в Україні сучасного Спортивного арбітражного суду.

Завдання дослідження, спрямовані на досягнення поставленої мети, полягають у:

- виявленні правової основи функціонування міжнародного спортивного арбітражу;

- зіставленні особливостей міжнародного спортивного арбітражного процесу 3 іншими видами діяльності міжнародних арбітражних процесів;

- вивчення міжнародної судової арбітражної практики в ставленні до спортсменів та федерацій різних країн, зокрема України.

Методи дослідження - аналіз й узагальнення літературних джерел; аналіз документальних матеріалів; метод історизму; метод аналогії досліджуваних закономірностей; системний аналіз.

Результати дослідження. Тематика досліджень міжнародного спортивного арбітражу визначає потребу всебічного розгляду цієї судової практики вирішення спортивних конфліктів, що виникають під час Олімпійських ігор, судової практики в розгляді справ, пов'язаних зі звинуваченнями в застосуванні допінгу та рішення з цих питань міжнародного спортивного арбітражу.

Основні принципи права, визнані всіма країнами, характерні також для сфери спорту, полягають у тому, що кожен має право на розгляд справи в суді, право на те, щоб справу було заслухано неупереджено й у відповідні терміни, право на презумпцію невинності, право на захист та ін. Норми, що містяться в статутах, положеннях й інших документах, що регламентують діяльність спортивних організацій, повинні визнаватися не тільки самими організаціями та їхніми членами, а й різними державними інстанціями. В іншому випадку порушники повинні бути піддані суворому осуду та навіть санкціям із боку Європейського суду 3 прав людини, створеного й діючого під егідою Свропейської ради, до повноправного членства в якій прагне Україна.

Міжнародний олімпійський комітет є ініціатором формування міжнародного чи трансидентного спортивного права. Доцільність такого рішення, на думку деяких фахівців [1; 14], визначається тим, що розгляд у звичайних судових інстанціях не пристосований до вирішення конфліктів серед учасників у сфері спортивної діяльності.

Спорт вищих досягнень, зокрема професійний, став однією $з$ найпрестижніших та високооплачуваних професій. Його стрімкий розвиток призвів до створення нової галузі професійної діяльності, яка 
має складноорганізовану структуру взаємозумовлених відносин членів суспільства найрізноманітніших напрямів професійної діяльності. У цьому ракурсі розвиток нової галузі затребуваної соціальної діяльності за своєю природою нічим не відрізняється від будь-якої іншої галузі соціально значущої діяльності. Тому іiі формування передбачає підготовку фахівців основної структури професійної діяльності, до яких входять не лише професійні спортсмени, але й фахівці, котрі забезпечують процес організації та управління цією галуззю. Як невід'ємна частина в структурі підготовки такого виду фахівців виступає специфічна галузь юриспруденції - спортивне право. 3 усієї різноманітності підготовки фахівців необхідного рівня для забезпечення ефективної роботи галузі найслабшою ланкою $є$ їх відсутність у галузі спортивного права. У низці країн підготовка вже здійснюється. В Україні цілеспрямована підготовка фахівців цієї професійної спрямованості повністю відсутня [10].

Нині працюють такі спортивні арбітражні суди, як Міжнародний спортивний арбітражний суд Le Tribunal Arbitral du Sport, спортивні арбітражні суди в Бельгії, Німеччині, Іспанії, Італії, Люксембурзі, Франції. Створено арбітражні суди в загальноєвропейських спортивних організаціях, таких як Свропейський народний спортивний рух [19].

Як уже відзначалося, створення Міжнародного спортивного арбітражного суду є ідеєю президента Міжнародного олімпійського комітету Хуана Антоніо Самаранча, викладеною ним на сесії МОК у БаденБадені.

Остаточне рішення про створення Міжнародного спортивного арбітражного суду прийнято Міжнародним олімпійським комітетом у 1983 р., що визначило створення органу врегулювання спорів, які виникають в олімпійському співтоваристві, котрим керує Міжнародний олімпійський комітет. Нині Спортивний арбітражний суд має повну незалежність і став міжнародним арбітражним судом, для якого характерні високі юридичні якості його роботи. Діяльність Міжнародного спортивного арбітражного суду отримала своє повне визнання в 1993 р., коли висока судова інстанція («Швейцарський федеральний суд») відзначила, що Спортивний арбітражний суд $є$ автономним арбітражним органом. Маючи у своєму розпорядженні статут та регламент, затверджений Міжнародним олімпійським комітетом, Спортивний арбітражний суд виносить вирок за матеріалами, які йому передаються на розгляд, грунтуючись на правах, що перебувають у його розпорядженні [6].

До компетенції Міжнародного спортивного арбітражного суду входять три основні функції:

1. Міжнародний спортивний арбітражний суд безпосередньо розглядає спори, що виникли в галузі спортивної діяльності, як арбітражний орган першої та останньої інстанції.

За роки своєї роботи Міжнародний спортивний арбітражний суд урегулював низку конфліктів. У результаті цієї роботи винесено рішення про розірвання трудового контракту з тренерами й ексклюзивного контракту на радіотрансляцію спортивних змагань; констатовано наявність міжнаціональної дискримінації в міжнародній федерації з приводу участі спортсменів у кваліфікаційних змаганнях; сформульовано визначення поняття контракту про спонсорство, що дає право спортсменам займатися додатковим видом спорту; установлено чіткі розмежування між подвійним громадянством гравців у баскетболі та їх єдиною спортивною приналежністю.

2. Виступати в ролі органу правового захисту й останньої інстанції з апеляції на прийняті рішення керівними органами міжнародних або національних федерацій та спортивних організацій.

Виконуючи цю функцію, Міжнародний спортивний арбітражний суд за час своєї роботи виніс низку вироків, заснованих на «наднаціональному» праві: відзначені випадки відхилення апеляцій, що надійшли до Спортивного арбітражного суду; коли апеляція була прийнята частково, із полегшенням накладених на спортсмена санкцій; коли апеляція була прийнята повністю, 3 анулюванням накладених санкцій міжнародної федерації стосовно спортсмена.

3. Давати юридичні консультації щодо основних проблем спортивної діяльності, не пов'язаних безпосередньо з виникненням суперечок.

У цьому напрямі роботи надано консультації з проблем про участь в Олімпійських іграх; щодо яких раніше застосовувалися санкції за вживання допінгу; визначення поняття «професійний спортивний журналіст»; сутності та змісту бойових мистецтв як виду спорту; виключення однієї національної федерації з членів міжнародної федерації [7].

За звітом президента Міжнародного спортивного арбітражного суду, його ресстр містить справи за вироками у сфері звичайної арбітражної практики; за апеляціями; консультації на прохання президента Міжнародного олімпійського комітету, спортивних федерацій та асоціацій журналістів [5].

Нині Міжнародний спортивний арбітражний суд зберігає свою незалежність, підтверджену результатами його діяльності й думкою Швейцарського федерального суду; конфіденційність, що проявляється в стриманості суду при прийнятті рішення та публікації матеріалів. 
Підсумки діяльності Міжнародного спортивного арбітражного суду підбито на міжнародній конференції «Право і спорт», організованій Міжнародним олімпійським комітетом у вересні 1993 р. в Лозанні на честь його десятої річниці. У роботі конференції взяли участь 180 представників «спортивно-судового» світу п'яти континентів: члени Міжнародного спортивного арбітражного суду та Швейцарського федерального суду, професори та магістри права, адвокати, керівники національних олімпійських комітетів і міжнародних федерацій, спортсмени [6].

Обговорення результатів 10-річної діяльності Міжнародного спортивного арбітражного суду показало необхідність його реформування, на що звернув свою увагу Швейцарський федеральний суд. Його дії зводилися до того, що з метою посилення гарантій прав сторін перед Міжнародним спортивним арбітражним судом у червні 1993 р. прийнято рішення про створення Міжнародної арбітражної ради в галузі спорту. Це рішення мало на меті зробити абсолютно незалежним Міжнародний спортивний арбітражний суд від Міжнародного олімпійського комітету. Для цього новоствореному органу передано відповідальність за забезпечення необхідних адміністративних і фінансових сторін діяльності Спортивного арбітражного суду.

При цьому передбачено кількісний склад і якісну структуру Міжнародної арбітражної ради у сфері спорту, яка повинна складатися з 20 юристів вищої кваліфікації, із яких по чотири особи призначає Міжнародний олімпійський комітет, міжнародні федерації, національні олімпійські комітети, спортсмени й сама рада з тих осіб, які не належать до названих вище організацій. Президента Міжнародної арбітражної ради у сфері спорту вони обирають зі своїх членів.

До головних функцій Міжнародної арбітражної ради у сфері спорту входить затвердження членів Міжнародного спортивного арбітражного суду, визначення фінансових внесків сторін для забезпечення роботи груп арбітрів, установлення внесків різних міжнародних спортивних організацій для фінансування судової діяльності та низка інших функцій.

Пропозицію щодо реформування діяльності Міжнародного спортивного арбітражного суду реалізовано в січні 1994 р. створенням Міжнародної арбітражної ради у сфері спорту, затвердженням Регламенту вирішення спорів, щзо виникають під час Олімпійських ігор, який застосовувався в процесі проведення Ігор XXVI Олімпіади в Атланті [6].

У рамках Міжнародного спортивного арбітражного суду запропоновано створити дві палати: Палату звичайного арбітражу, яка повинна вирішувати спори приватного характеру, що безпосередньо виникають у спортивній практиці, і Палату апеляційного арбітражу, яка повинна виносити рішення щодо апеляцій. Отже, реформування спрямовано на диференціацію діяльності суду в рамках виконання ним функцій.

Подальше реформування та вдосконалення діяльності суду пов'язане з визнанням міжнародними й національними федераціями, національними олімпійськими комітетами та іншими спортивними організаціями факту, що Міжнародний спортивний арбітражний суд є єдиним компетентним судовим органом щодо апеляцій проти рішень внутрішніх судових інстанцій.

Основні нормативно-правові документи, котрі регламентують діяльність Міжнародного спортивного арбітражного суду, є Статут і Регламент, затверджені 30 червня 1984 р. Доповнення та зміни в ці нормативно-правові документи внесено 20 вересня 1990 р. Кодекс Міжнародного спортивного арбітражу, який набув чинності 22 листопада 1994 р., у 2003 р. піддався істотній переробці, грунтуючись на правових принципах, вироблених практикою суду. Нова редакція Кодексу включає дві частини - установчу й процесуальну. Установча частина містить положення про органи суду, процесуальна визначає арбітражний регламент, апеляційний регламент, регламент процедури примирення за участю посередника та положення про консультаційні висновки Спортивного арбітражного суду [16].

Регламент вирішення спорів, що виникають під час Олімпійських ігор, є складовою частиною Кодексу міжнародного спортивного арбітражу. Статут та Регламент визначають основні положення діяльності Міжнародного спортивного арбітражного суду, до провідних серед яких відносять:

- місцезнаходження Міжнародного спортивного арбітражного суду - місто Лозанна (Швейцарська Конфедерація);

- компетениію Міжнародного спортивного арбітражного суду, яка полягає в розгляді спорів різного характеру, що виникають у практиці розвитку спорту й будь-якої діяльності, пов'язаної 3 конфліктними ситуаціями, вирішення яких не передбачено Олімпійською Хартією;

- склад Міжнародного спортивного арбітражного суду, що представляється чисельністю не більше ніж 60 осіб, які мають юридичну освіту та визнану компетенцію в галузі спорту. Призначення членів Міжнародного спортивного арбітражного суду проводиться Міжнародним олімпійським комітетом, 
міжнародними федераціями, національними олімпійськими комітетами й особисто президентом МОК (по 15 осіб у кожному випадку). МОК, НОК і міжнародним федераціям рекомендовано дотримуватися під час їх призначення такого географічного розподілу членів суду: Європа - шість, Африка - три, Америка три, Азія - два, Океанія - один. Представників України на сьогодні в складі Міжнародного спортивного арбітражного суду немає.

Список членів Міжнародного спортивного арбітражного суду публікується в алфавітному порядку в засобах масової інформації, що виходять у місці розміщення штаб-квартири суду. Після свого призначення всі члени Міжнародного спортивного арбітражного суду підписують індивідуальну урочисту заяву.

Керівництво Міжнародним спортивним арбітражним судом здійснюється головою, який $є$ членом МОК і призначається на посаду президентом МОК. Голова суду керує діяльністю канцелярії, очолюваної генеральним секретарем. Члени канцелярії й персонал суду призначаються президентом МОК [14].

Дискусія. Конфліктні ситуації, які розглядаються в спортивних і третейських судах, розкривають початкові причини, що породжують їх. Короткий огляд матеріалів наведених вище авторів дає змогу 3 достатньою повнотою оцінити особливості розвитку та формування структури конфліктів і шляхи врегулювання конфліктних ситуацій у галузі спортивного права, яка розвивається. Як і в будь-якій іншій галузі, головний принцип боротьби 3 конфліктами, що виникають, грунтується на карних мірах, а не на застережних мірах причин, які породжують ці конфлікти [17].

Питання про неспроможність карних мір у боротьбі з конфліктами в системі соціальних взаємозумовлених відносин розглядали Ніколо Макіавеллі в праці «Государ» (1532р.), Шарль Луї де Монтеск'є в розвідці «Про дух законів» (1748р.), Чезаре Беккаріа в дослідженні «Про злочини та покарання» (764р.) [3]. Зрозуміло, що в них були попередники, історія яких сягає давнини, та ціла плеяда послідовників. Однак причина безуспішної реалізації їхніх ідей обгрунтована лише появою у світі праці Лофті Заде 3 теорії нечітких множин, у якій він описав математичний апарат теорії нечітких множин (1965 р.). У 1973 р. він запропонував теорію нечіткої логіки. Ці праці покладено в основу побудови теорії толерантних просторів [18].

Подальший розвиток цієї теорії дав змогу установити залежність між мірою толерантності просторів та доступної складності організації взаємозумовлених соціальних процесів [9].

Природний емпіричний шлях побудови сучасної системи управління в галузі спорту вищих досягнень, яка формується, пролягає через метод спроб і помилок, підкоряючись законам загальної теорії самоорганізації, яка отримала своє завершення в другій половині XX ст. появою теорії синергетичних систем [13].

Загальна теоретична основа проблеми переоріснтації правових норм від карних мір боротьби 3 результатами конфліктів до профілактичних мір їх попередження з достатньою повнотою обгрунтована в працях О. М. Бандурки [3, 4]. Однак ідеться не про відміну карних мір в обмін на профілактичні, а про їх спільне вдосконалення в розвитку нової галузі спортивного права. Це може бути досягнуто лише введенням кількісних методів оцінки виконуваної діяльності, яка відбувається в умовах толерантних відносин з усіма відповідними вимогами, що виходять із цих умов і принципів організації, що визначають їх перебіг. Одним із таких визначальних принципів є статистичне формування еквіфінального кінцевого результату та його безперервна динаміка як результат опосередкування діяльності, що й визначає особливості перебігу іï подальшого формування. Наявність сучасних досягнень комп'ютерної техніки, програм обробки отриманої інформації в ознакових семантичних просторах з уведеною в них єдиною мірою, що дасть змогу не лише значно прискорити та збільшити обсяг переробки інформації, але й прогнозувати подальший хід перебігу подій [2; 11].

Природу виникнення конфліктів досить повно розкрито в юридичній літературі $[3 ; 4 ; 8]$. Конфлікти $\epsilon$ невід'ємним компонентом у соціальній організації спільних взаємозумовлених відносин, їх неминучість залежить від толерантності середовищних взаємодій. Своєчасне усунення причин, які породжують розвиток конфліктних ситуацій, значно скоротить навантаження арбітражних і третейських судів. Розв'язання цієї проблеми розглядалось автором у попередніх публікаціях [12]. Результати нашого дослідження доповнюють результати наукового пошуку, представлені у вищезазначених працях. Основою є необхідний рівень спостережливості за діяльністю спортивних клубів і федерацій з установленою системою електронної звітності по вертикалі їх підпорядкованості. Кожен ранг рівня організації звітності має відповідну автономію можливості розв'язання спірних ситуацій, які виникають, і може з більш глибокою деталізацією розглянути конфлікт, що розвивається в межах адміністративних заходів його врегулювання.

Висновки та перспективи подальших досліджень. 3'ясовано найбільш характерні недоліки наявної системи організації правової діяльності в спорті, якими виступають суб'єктивність оцінки та при- 
йняття рішень у конфліктних ситуаціях, що виникають; відсутність єдиної електронної бази відповідних інститутів, які виконують правову діяльність у сфері спортивних відносин; відсутність будь-якої кількісної оцінки прояву їхніх якісних характеристик.

Виявлено, що всі спостережувані ускладнення вертикальних надбудов контролю, диференціації професійної діяльності на шляху інтеграції світового співтовариства неодмінно призводять до невиконання поставлених завдань і зростання їх вартості. Аналіз причин цього процесу призводить до необхідності звернення до загальної теорії систем, що самоорганізуються.

Установлено головну причину невирішення наявних труднощів в управлінні галуззю спорту вищих досягнень, яка полягає в недостатній мірі спостережливості на кожному рівні організації цісї структури за розвитком конфліктних ситуацій та можливості їх попередження на початковій стадії розвитку. Це дає змогу перейти від карних мір боротьби з результатами конфліктів до профілактичних мір їх попередження.

Перспективи подальших досліджень пов'язуємо з тим, що використання цього підходу дасть змогу створити більш ефективну правову основу організації системи управління спортивними клубами, федераціями та роботи арбітражних і третейських судів у спорті як державну, так і єдину міжнародну систему, яка об’єднає в єдине правове поле всі державні системи, що входять у загальну асоціацію.

\section{Джерела та література}

1. Алексеев С. В. Международное спортивное право: учеб. для вузов/под ред. П. В. Крашенинникова. Москва: Закон и право: ЮНИТИ-ДАНА, 2008. 895 с.

2. Ашанин В. С., Пугач Я. И. Построение семантических пространств для описания психологической деятельности человека в экстремальных условиях: учеб. пособие. Харьков: ХГАФК, 2014. 88 с.

3. Бандурка А. М. Психология толпы. Харьков : ООО Титул, 2006. 208 с.

4. Бандурка А. М., Друзь В. А. Конфликтология. Харьков: РИП Оригинал Фортуна-пресс, 1997. 356 с.

5. Каменков В. С. Современные мысли о спортивном арбитраже. Спорт, экономика, право, управление. 2012. № 2. C. 19-22.

6. Кузин В. В., Кугепов М. Е., Холодняк Д. Г. Спортивный арбитраж. Москва: Физкультура, образование и наука, 1996. 165 с.

7. Николюкин С. В. Спортивные арбитражи как регуляторы конфликтов в области спорта. Спорт: экономика, право, управление. 2011. № 4. С. 21-25.

8. Орлова С. В. Психологические аспекты эффективности правового регулирования общественных отношений. Научно-методический электронный журнал «Конщепт». 2015. T. 13. C. 3141-3145. URL: http://e-koncept.ru/2015/85629.htm. (дата звернення 25.04.2019).

9. Самсонкин В. Н., Друзь В. А., Федорович Е. С. Моделирование в самоорганизующихся системах. Донецк, 2010. $104 \mathrm{c}$.

10. Саннікова М. В. Онтологія розвитку галузі спортивного права. Фізичне виховання, спорт і культура здоров'я у сучасному суспільстві/уклад. А. В. Цьось, С. Я. Індика. Луцьк: Східноєвроп. нац. ун-т ім. Лесі Українки, 2018. № 4(44). С. 3-9. doi.org/10.29038/2220-7481-2018-04-03-09

11. Саннікова М. В. Характеристика соціальних конфліктів у сфері фізичної культури та спорту. Фізичне виховання, спорт і культура здоров'я у сучасному суспільстві/уклад. А. В. Цьось, С. Я. Індика. Луцьк: Східноєвроп. нац. ун-т ім. Лесі Українки, 2019. № 1(45). С. 22-28. doi.org/10.29038/2220-7481-2019-01-22-28

12. Саннікова М. Організаційно-правові умови створення спортивного арбітражу в Украӥні. Слобожанський науково-спортивний вісник. 2019. № 2. С. 64-68.

13. Хаган Г. Синергетика иерархии неустойчивостей у самоорганизующихся системах и устройствах. Москва, $1985.420 \mathrm{c}$.

14. Бриллиантова А. М., Кузин В. В., Кугепов М. Е. Энциклопедия олимпийского арбитража: Атланта-НаганоСидней / Москва: Физкультура и спорт, 2005. 346 с.

15. Helen Jefferson Lenskyj. Sport exceptionalism and the Court of Arbitration for Sport. Journal of Criminological Research, Policy and Practice. 2018. Vol. 4 № 1, P. 5-17. doi.org/10.1108/JCRPP-01-2018-0002. URL: https://www.researchgate.net/publication/322595826 (дата звернення: 4.02.2019).

16. Hergüner Bilgen Özeke. Law in Sports: International Sports Arbitration, Newsletter Hergüner Bilgen Özeke Attorney Partnership. 2017. URL: https://s3.amazonaws.com/documents.lexology.com/13elf729-4ad7-4977-949f597679774e59.pdf (дата звернення: 12.02.2019).

17. Holt N. L., Knight C. J. \& Zukiwski P. Femaleathletes' perceptions of teammate conflict in sport: Implications for sport psychologyconsultants. The Sport Psychologist. 2012. № 26. P. 135-154.

18. Lotfi Zadeh. From computing with numbers to computing with words - from manipulation of measurements to manipulation of perceptions. International Journal of Applied Math and Computer Science. 2002. Vol. 12. № 3. P. 307-324. URL: http://matwbn.icm.edu.pl/ksiazki/amc/amc12/amc1231.pdf (дата звернення: 24.03.2019). 
19. Matthew Buckle. Court of arbitration for sport (CAS). Norton Rose Fulbright Logo Search. 2018. URL: https://www.nortonrosefulbright.com/en/knowledge/publications/048b7aeb/court-of-arbitration-for-sport-cas (дата звернення: 12.04.2019).

\section{References}

1. Alekseev, S. V. (2008). Mezhdunarodnoe sportivnoe pravo [International Sports Law]: ucheb.dlya vuzov / P. V. Krasheninnikov (Red.). Moskva: Zakon i pravo: YuNITI-DANA, 895.

2. Ashanin, V. S, Pugach, Ya. I. (2014). Postroenie semanticheskih prostranstv dlya opisaniya psihologicheskoy deyatelnosti cheloveka v ekstremalnyih usloviyah [Building semantic spaces to describe a person's psychological activity under extreme conditions], Ucheb. posobie. Harkov: HGAFK, 88.

3. Bandurka A. M. (2006). Psihologiya tolpyi [Crowd psychology]. Harkov: OOO Titul, 208.

4. Bandurka, A. M., Druz, V. A. (1997). Konfliktologiya [Conflict]: uchebnoe posobie dlya vuzov. Harkov: Un-t vnutr.del, 356.

5. Kamenkov, V. S. (2012). Sovremennyie myisli o sportivnom arbitrazhe [Modern thoughts on sports arbitration]. Sport, ekonomika, pravo, upravlenie, 2, 19-22.

6. Kuzin, V. V., Kutepov, M. E., Holodnyak, D. G. (1996). Sportivnyiy arbitrazh [Sports Arbitration] Moskva: FON, 165.

7. Nikolyukin, S. V. (2011). Sportivnyie arbitrazhi kak regulyatoryi konfliktov v oblasti sporta [Sports arbitration as regulators of conflicts in the field of sports]. Sport: ekonomika, pravo, upravlenie, 4, 21-25.

8. Orlova, S. V. (2015). Psihologicheskie aspektyi effektivnosti pravovogo regulirovaniya obschestvennyih otnosheniy [Psychological aspects of the effectiveness of legal regulation of social relations]. Nauchno-metodicheskiy elektronnyiy zhurnal «Kontsept», 13, 3141-3145. URL: http://e-koncept.ru/2015/85629.htm. (data zvernennya 25.04.2019).

9. Samsonkin, V. N., Druz, V. A., Fedorovich, E. S. (2010). Modelirovanie v samoorganizuyuschihsya sistemah [Modeling in self-organizing systems]. Donetsk, 104.

10. Sannikova, M. V. (2018). Ontolohiia rozvytku haluzi sportyvnoho prava [Ontology of sports law development]. Physical Education, Sports and Health Culture in Modern Society/ A. V. Tsos, S. Ya. Indyka (uklad.). Lutsk: Skhidnoievrop. nats. un-t im. Lesi Ukrainky, 4(44), 3-9. doi.org/10.29038/2220-7481-2018-04-03-09

11. Sannikova, M. V. (2019)/ Kharakterystyka sotsialnykh konfliktiv u sferi fizychnoi kultury ta sportu [Characteristics of social conflicts in the field of physical culture and sports]. Physical Education, Sports and Health Culture in Modern Society/ A. V. Tsos, S. Ya. Indyka (uklad.). Lutsk : Skhidnoievrop. nats. un-t im. Lesi Ukraink, 1(45), 2228. doi.org/10.29038/2220-7481-2019-01-22-28

12. Sannikova, M. (2019). Orhanizatsiino-pravovi umovy stvorennia sportyvnoho arbitrazhu v Ukraini [Organizational and legal conditions for the creation of sports arbitration in Ukraine]. Slobozhanskyi naukovo-sportyvnyi visnyk, 2 , 64-68.

13. Hagan, G. (1985). Sinergetika ierarhii neustoychivostey u samoorganizuyuschihsya sistemah i ustroystvah [Synergetics of the hierarchy of instabilities in self-organizing systems and devices]. Moskva, 420.

14. Brilliantova, A. M., Kuzin, V. V., Kutepov, M. E. Entsiklopediya olimpiyskogo arbitrazha: Atlanta-Nagano-Sidney (2005). Moskva: Fizkultura i sport, 346.

15. Helen Jefferson Lenskyj (2018). Sport exceptionalism and the Court of Arbitration for Sport. Journal of Criminological Research, Policy and Practice, 4, 1, 5-17.

16. Hergüner Bilgen Özeke (2017). Law in Sports: International Sports Arbitration. Newsletter Hergüner Bilgen Özeke Attorney Partnership. URL: https://s3.amazonaws.com/documents.lexology.com/13e1f729-4ad7-4977-949f597679774e59.pdf

17. Holt, N. L., Knight, C. J. \& Zukiwski, P. (2012). Femaleathletes' perceptions of teammate conflict in sport: Implications for sport psychologyconsultants. The Sport Psychologist, 26, 135-154.

18. Lotfi, Zadeh (2002). From computing with numbers to computing with words - from manipulation of measurements to manipulation of perceptions. International Journal of Applied Math and Computer Science, 12, 3, 307-324. URL: http://matwbn.icm.edu.pl/ksiazki/amc/amc12/amc1231.pdf

19. Matthew, Buckle (2018)/ Court of arbitration for sport (CAS). Norton Rose Fulbright Logo Search. URL: https://www.nortonrosefulbright.com/en/knowledge/publications/048b7aeb/court-of-arbitration-for-sport-cas.

Стаття надійшла до редакції 20.05.2019 р. 